\title{
AKTYWNOŚĆ REKREACYJNO-TURYSTYCZNA W CZASIE WOLNYM PIEKAREK NOŻNYCH Z WOJEWÓDZTWA ŁÓDZKIEGO ${ }^{1}$
}

\section{Wstęp}

W końcu XX i w pierwszych dekadach XXI w. ludzie są coraz bardziej aktywni zarówno w sferze zawodowej, jak i w innych dziedzinach życia. Postęp cywilizacyjny stwarza człowiekowi wiele możliwości wyboru form aktywności w czasie wolnym. Francuski socjolog J. Viard policzył, że w ciągu ostatnich 100 lat czas trwania ludzkiego życia wydłużył się średnio z 500 do 700 tys. godzin, natomiast czas pracy zmniejszył się z 200 tys. do 67 tys. godzin (Viard, 2002). To dowodzi, że praca nie pochłania już prawie połowy życia człowieka. Pod koniec XVIII w. przeciętny robotnik miał w ciągu życia 100 tys. godzin czasu wolnego, obecnie jego ilość wzrosła i wspóczesny człowiek ma go cztery razy więcej. Dzięki temu może sobie pozwolić na jego aktywne wykorzystanie, uczestnicząc $w$ rekreacji i turystyce.

Piłka nożna jest jedną z najpopularniejszych form rekreacji w Polsce. To dyscyplina, którą uprawiają nie tylko mężczyźni, ale również kobiety - mają swoje rozgrywki, wyjeżdżają na zgrupowania i mecze, odnoszą sukcesy i ponoszą porażki. Sport ten w wykonaniu pań ma coraz szersze grono zainteresowanych. Kobieca piłka nożna jest niewiele młodsza od męskiej. Jak podaje Pol (2016), początki kobiecego futbolu datuje się na koniec XIX w. Jego kolebką, podobnie jak w przypadku mężczyzn, była Anglia. Ze

\footnotetext{
${ }^{1}$ Artykuł powstał na podstawie pracy magisterskiej pt. Aktywność rekreacyjno-turystyczna $w$ czasie wolnym piłkarek nożnych z województwa tódzkiego (2018) napisanej w Uniwersytecie Łódzkim pod kierunkiem prof. UŁ dr hab. Jolanty Wojciechowskiej.
} 
względu na czasy niesprzyjające przełamywaniu stereotypów kobiety, aby spełnić swoje sportowe marzenia, miały do pokonania trudniejszą drogę niż mężczyźni. Jednak dzięki zaangażowaniu oraz wytrwałości miłośniczek piłki nożnej ta dyscyplina rozwijała się i przetrwała do dziś. Powstały też liczne organizacje, kluby oraz odbyło się wiele wydarzeń sportowych w piłce nożnej kobiet. Na dowód tego można przytoczyć w pełni profesjonalne ligi piłkarskie kobiet, takie jak np. Bundesliga (Niemcy), Toppserien (Norwegia) czy WPS (Stany Zjednoczone) (WP. Kobieta...). Obecnie grono kobiet uprawiających piłkę nożną stale rośnie. Z tego powodu piłkarki nożne stały się w niniejszym opracowaniu podmiotem badań autorki.

\section{Cele i metody badań}

Decydując się na temat badań, autorka kierowała się własnymi zainteresowaniami - od kilkunastu lat trenuje bowiem piłkę nożną w klubie w Tomaszowie Mazowieckim. Jak wspomniano wcześniej, piłkarki nożne z województwa łódzkiego stały się podmiotem badań, a przedmiotem badań - ich aktywność rekreacyjno-turystyczna w czasie wolnym.

Niniejsza praca ma na celu zbadanie ilości czasu wolnego piłkarek nożnych z województwa łódzkiego oraz sprawdzenie, w jaki sposób jest on wykorzystywany. Problemem badawczym było natomiast ustalenie, czym się charakteryzuje oraz wyróżnia aktywność rekreacyjno-turystyczna kobiet grających $\mathrm{w}$ piłkę nożną. Postawiono więc następującą hipotezę: $\mathrm{w}$ im wyższej lidze rozgrywkowej znajduje się drużyna zawodniczki, tym aktywniej spędza ona czas wolny.

Główną metodą badawczą zastosowaną w pracy był wywiad kwestionariuszowy. Badania ankietowe zostały przeprowadzone we wrześniu i październiku 2017 r. z zawodniczkami pięciu łódzkich drużyn piłkarskich. W przypadku ankiet skierowanych do piłkarek nożnych zastosowano metodę badań losowych, tj. dobór losowy prosty drużyn, w których grają zawodniczki. Spośród 17 łódzkich klubów wylosowano pięć. Jedną drużyną były zawodniczki z ekstraligi, po jednej drużynie wybrano z I ligi i II ligi oraz dwa zespoły z III ligi. Początkowo w badaniu miały wziąć udział cztery drużyny, co odpowiada liczbie lig utworzonych w PZPN i ŁZPN (ekstraliga, I liga, II liga, III liga), jednak napotkano pewne trudności. Ze względu na małe zainteresowanie zawodniczek badaniem, negatywne 
nastawienie do niego oraz niewielki odzew ze strony jednego z klubów, postanowiono wyłonić do badania dodatkową drużynę z III ligi. Z tego powodu pierwsze losowanie zostało anulowane, następnie powtórzono losowanie, a jedyną zmianą było wylosowanie dwóch drużyn z urny z klubami znajdującymi się w III lidze. Wyniki próby przedstawia tab. 1.

Tab. 1. Wyniki wyboru losowego do badań ankietowych w sezonie 2016/2017 r. drużyn piłkarskich kobiet z woj. łódzkiego

\begin{tabular}{|c|l|c|c|c|}
\hline $\begin{array}{c}\text { Numer } \\
\text { losowania } \\
\text { przypisany } \\
\text { drużynie }\end{array}$ & Nazwa drużyny & $\begin{array}{c}\text { Liga, w której } \\
\text { znajduje się } \\
\text { drużyna }\end{array}$ & $\begin{array}{c}\text { Liczba za- } \\
\text { wodniczek }\end{array}$ & $\begin{array}{c}\text { Losowy } \\
\text { wybór } \\
\text { drużyny }\end{array}$ \\
\hline 1 & UKS SMS Łódź & ekstraliga & 29 & + \\
\hline 2 & UKS SMS II Łódź & I & 30 & - \\
\hline 3 & MUKS Dargfil Tomaszów Maz. & I & 31 & + \\
\hline 4 & UMKS Włókniarz Zgierz & II & 27 & + \\
\hline 5 & Pogoń Zduńska Wola & II & 20 & - \\
\hline 6 & Kolejarz Łódź & III & 26 & - \\
\hline 7 & Róża Kutno & III & 19 & - \\
\hline 8 & Bękitni Dmosin & III & 19 & - \\
\hline 9 & ULKS MOSIR Sieradz & III & 20 & + \\
\hline 10 & MGUKS Pogoń Zduńska Wola & III & 20 & - \\
\hline 11 & MKS Expom Krośniewianka & III & 22 & - \\
\hline 12 & PTC Pabianiace & III & 20 & - \\
\hline 13 & Wojownik Skierniewice & III & 25 & - \\
\hline 14 & MKS Zduńska Wola & III & 26 & - \\
\hline 15 & Zawisza Fiero Rzgów & III & 23 & - \\
\hline 16 & UKS Piotrcovia Piotrków Tryb. & III & 30 & + \\
\hline 17 & Kotan Ozorków & III & 18 & - \\
\hline
\end{tabular}

Objaśnienia: „," oznacza wylosowaną drużynę; „,-" oznacza niewylosowaną drużynę. Źródło: opracowanie własne.

Odpowiedni dobór drużyn piłkarskich spowodował, że przeprowadzone badania są reprezentatywne, gdyż zbiorowość próbna, czyli piłkarki z wybranych zespołów, stanowi statystyczną reprezentację całej zbiorowości z województwa łódzkiego. W sezonie 2016/2017 w województwie łódzkim było zarejestrowanych 405 piłkarek nożnych, a badania przeprowadzono ze 132 zawodniczkami. Dokonano ponadto inwentaryzacji bezpośredniej badanych klubów, czyli spisu faktycznego stanu zagospodarowania sportowego w każdej drużynie. 


\section{Charakterystyka badanych klubów}

W badaniach wzięły udział następujące drużyny piłkarskie:

- Uczniowski Klub Sportowy (UKS) SMS Łódź (ekstraliga);

- Międzyszkolny Uczniowski Kub Sportowy (MUKS) Dargfil Tomaszów Mazowiecki (I liga, grupa północna);

- Uczniowski Międzyszkolny Kub Sportowy (UMKS) Zgierz (II liga, grupa mazowiecka),

- UKS Piotrcovia Piotrków Trybunalski (III liga, grupa łódzka);

- Uczniowski Ludowy Klub Sportowy (ULKS) MOSIR Sieradz (III liga, grupa łódzka).

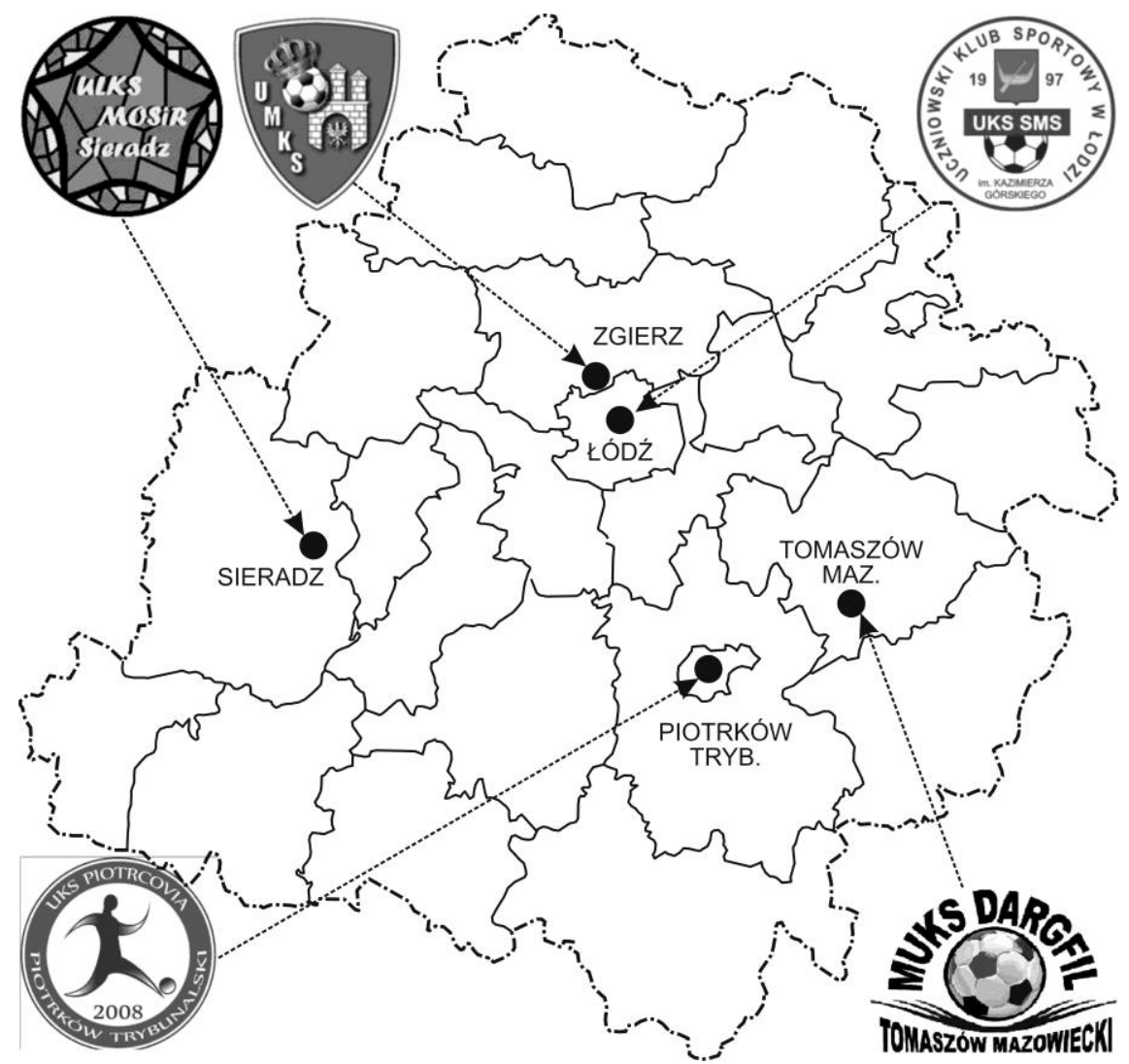

Rys. 1. Rozmieszczenie analizowanych klubów piłki nożnej kobiet w sezonie 2016/2017 w woj. łódzkim

Źródło: rys. 1-18: opracowanie własne na podstawie wyników badań ankietowych w 2017 r. 
Wybrane do badań kluby znajdowały się w następujących miastach: Łódź, Piotrków Trybunalski, Tomaszów Mazowiecki, Sieradz i Zgierz (rys. 1). Prawie wszystkie drużyny miały swoje siedziby w centrum miasta, jedynie ULKS MOSiR Sieradz był zlokalizowany na peryferiach miasta. Zespoły żeńskie działały przy męskich drużynach piłkarskich bądź przy innych klubach sportowych, co pozwalało na szersze promowanie kobiecej piłki nożnej wśród różnych dziedzin sportu.

Prawie wszystkie badane drużyny powstały w XXI w., jedynie klub MUKS Dargfil Tomaszów Mazowiecki może pochwalić się dłuższą historią (rok założenia 1997) i osiągnięciami. Żeńskie sekcje piłki nożnej zazwyczaj są tworzone przez pasjonatów, którzy widząc zaangażowanie i wolę walki dziewcząt, aktywnie włączają się w promowanie piłki nożnej kobiet w swoich rejonach.

Najbardziej ubogim zagospodarowaniem sportowym w 2016 r. charakteryzował się stadion w Tomaszowie Mazowieckim. Znajdowało się w nim jedno boisko do gry, które miało sztuczną nawierzchnię, dzięki czemu treningi mogły być prowadzone zarówno latem, jak i wtedy, kiedy na płycie boiska leżał śnieg. Zdecydowanie najlepszą infrastrukturę piłkarską posiadał SMS Łódź. Tutaj piłkarki w jednym miejscu miały zarówno bazę treningową, jak i szkołę oraz odnowę biologiczną, lekarza i salę do rehabilitacji. Najbogatszą infrastrukturą sportową wyróżniał się natomiast MOSiR, mieszczący się w Sieradzu (fot. 1), z którego boisk piłkarki korzystały dwa razy $w$ tygodniu, jako że nie posiadały własnego stadionu. W obiekcie jednocześnie mogło odbywać się wiele imprez sportowych i wydarzeń dla rodzin z dziećmi.

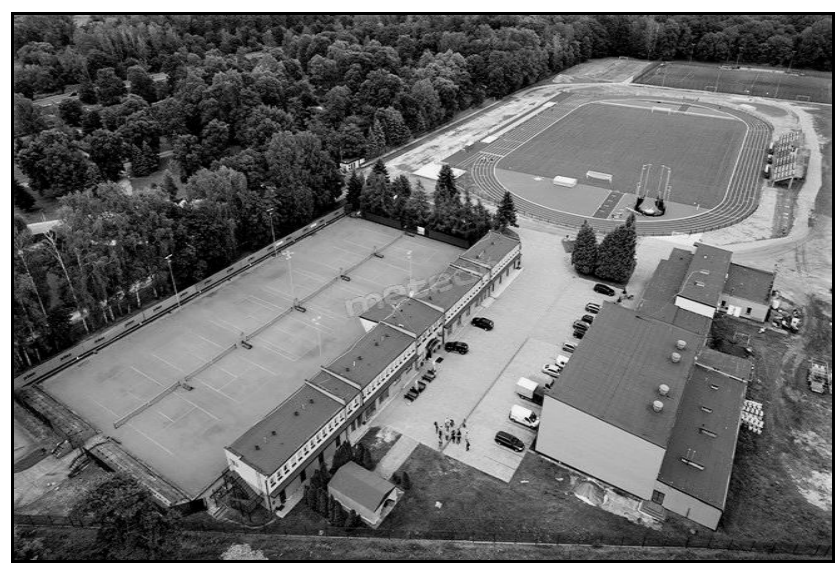

Fot. 1. Stadion ULKS MOSiR Sieradz Źródło: Miejski Ośrodek Sportu i Rekreacji w Sieradzu... 


\section{Profil społeczno-demograficzny piłkarek i czas poświęcany przez nie na zajęcia obowiązkowe}

Zawodniczki w 95,5\% zamieszkiwały województwo łódzkie (rys. 2), a najwięcej piłkarek (prawie 29\%) pochodziło z powiatu łódzkiego. Na drugim miejscu, z udziałem 25,5\% respondentek, znalazły się panie z powiatu piotrkowskiego. Wszystkie zawodniczki z ULKS MOSiR Sieradz zamieszkiwały powiat sieradzki.

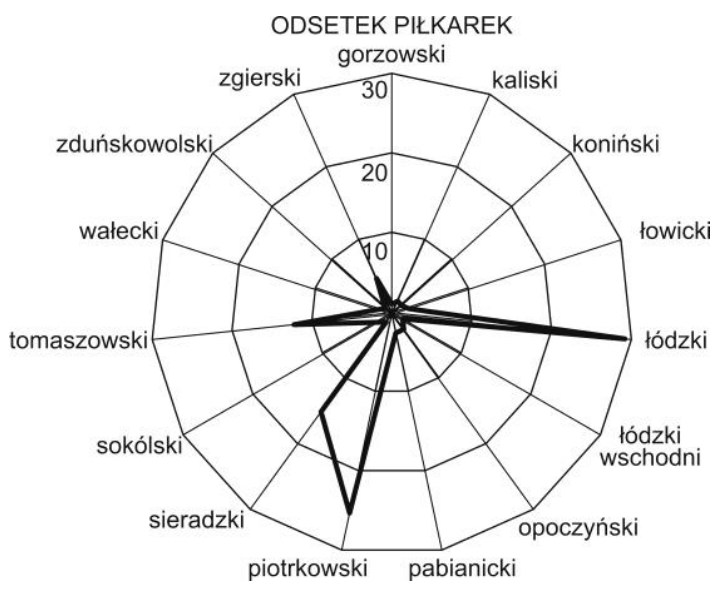

Rys. 2. Miejsce zamieszkania badanych piłkarek nożnych zarejestrowanych w klubach piłkarskich woj. łódzkiego w 2016 r. według powiatów $(\mathrm{n}=132)$

Respondentki stanowiły grupę dość młodych osób, gdyż średnia wieku zawodniczek wynosiła nieco ponad 19 lat. Może to wynikać $\mathrm{z}$ faktu, iż piłkarki w Polsce swoją karierę sportową zaczynają w wieku kilkunastu lat, a kończą ją zazwyczaj przed 30. rokiem życia (rys. 3). Najmłodsze zawodniczki odnotowano z UKS Piotrcovia, gdzie ponad $60 \% \mathrm{z}$ nich reprezentowało przedział wieku 10-15 lat. To bardzo młode, dojrzewające dziewczyny - w tej drużynie nie ma piłkarki, która ukończyłaby 20. rok życia. Równie młodym zespołem był ULKS MOSiR Sieradz, w którym prawie 50\% członkiń znalazło się w najniższym przedziale wiekowym. W Tomaszowie Mazowieckim odpowiedzi na pytanie o wiek rozkładały się dosyć równomiernie, z przewagą osób powyżej 15. roku życia. Warto jedynie wskazać, że pośród ankietowanych zawodniczek z UKS SMS Łódź oraz UMKS Zgierz nie było piłkarki mającej mniej niż 15 lat. 
UKS Piotrcovia Piotrków Tryb.

ULKS MOSiR Sieradz

UMKS Zgierz

MUKS Dargfil Tomaszów Maz.

UKS SMS Łódź

Wiek zawodniczek
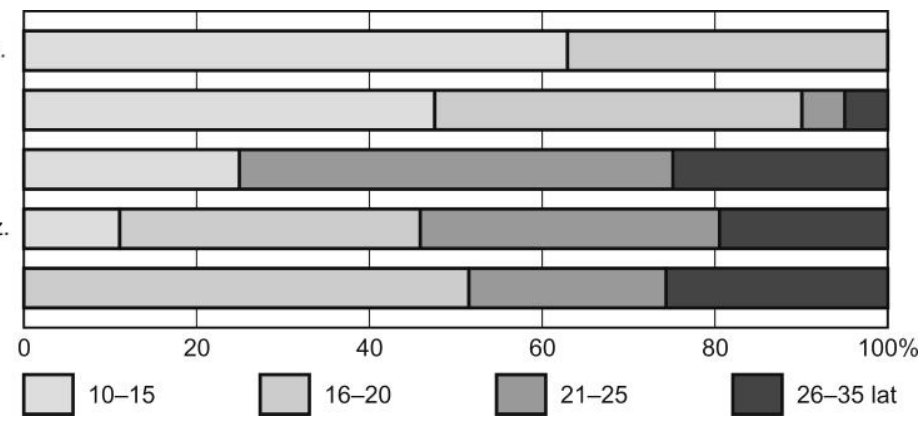

26-35 lat

Rys. 3. Struktura wieku zawodniczek w 2016 r. w badanych drużynach piłkarskich z woj. łódzkiego

Po przeprowadzeniu badań ankietowych pośród zawodniczek wybranych drużyn piłki nożnej z województwa łódzkiego w 2016 r. autorka stwierdziła różnice $\mathrm{w}$ wieku oraz poziomie wykształcenia tych osób. Ze względu na dominujący wiek poniżej 20 lat zdecydowaną większość z piłkarek stanowiły osoby uczące się (uczennice lub studentki), które miały podstawowe lub średnie wykształcenie. Wśród ogółu respondentek przeważało wykształcenie średnie, natomiast w klubach III-ligowych - podstawowe albo średnie. W zespołach znajdujących się w lidze II, I oraz w ekstralidze zawodniczki charakteryzował zróżnicowany poziom wykształcenia, co przedstawiono na rys. 4, niemniej jednak w badanych zespołach piłkarskich wyższym wykształceniem legitymowała się mniej niż połowa kobiet.

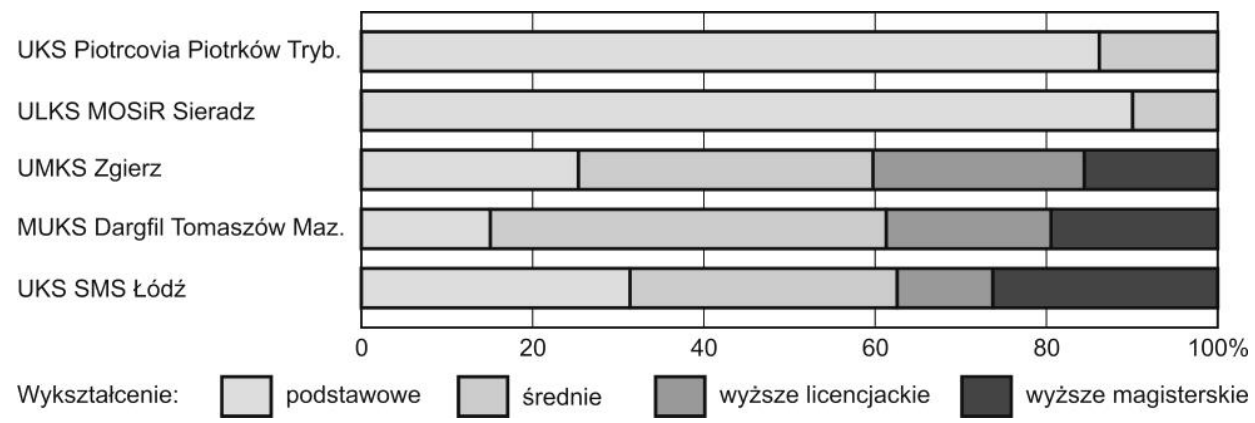

Rys. 4. Struktura wykształcenia respondentek w 2016 r.

Badaniu poddano także długość czasu poświęcanego przez piłkarki na zajęcia obowiązkowe, do których należały: uczestnictwo w lekcjach w szkole lub zajęciach na uczelni, praca oraz codzienne powinności. Okres jesienny, 
podczas którego zawodniczki spędzały w szkole bądź w pracy średnio 6-7 godzin dziennie, był zdecydowanie bardziej wypełniony zajęciami życia codziennego (rys. 5).

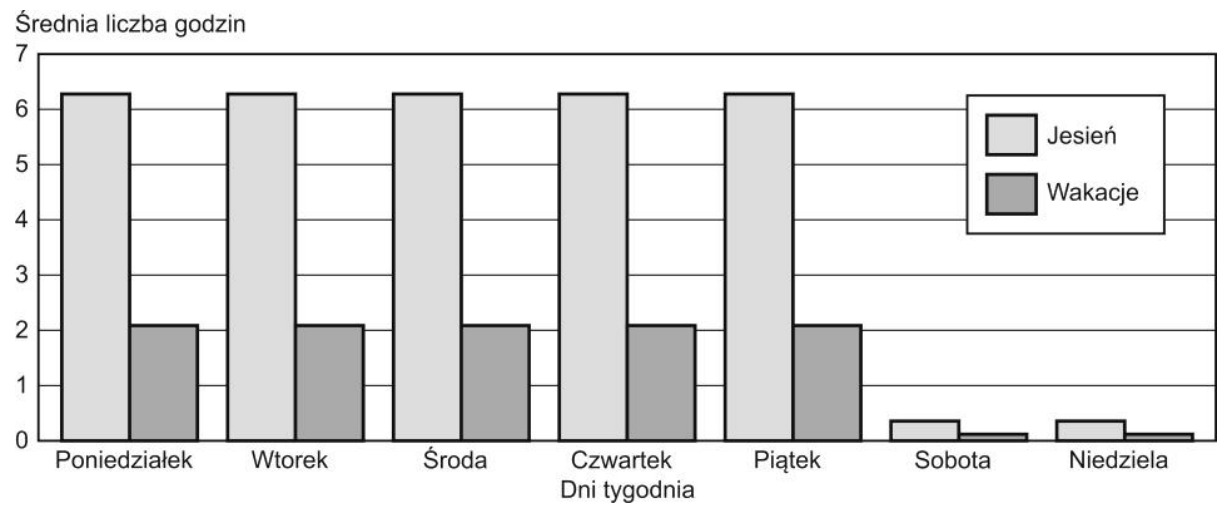

Rys. 5. Średnia liczba godzin spędzonych w szkole/pracy przez respondentki $\mathrm{w} 2016 \mathrm{r}$.

Rozkład godzinowy dnia piłkarek nożnych pokrywa się z wynikami badań przeprowadzonych w 2013 r. przez Główny Urząd Statystyczny. Tematem pomiarów, które prowadzane są co 10 lat, był „Budżet czasu ludności w 2013 roku". W badaniu prowadzonym przez GUS (Budżet czasu..., 2015) był stosowany podział na dwie grupy wiekowe: 10-14 lat oraz 15 lat i więcej, a 52,6\% próby stanowiły kobiety. Według GUS na pracę zawodową osoby ją wykonujące poświęcały średnio 7 godzin i 38 minut dziennie, natomiast dzieci w wieku 10-14 lat spędzały dziennie średnio 5 godzin i 56 minut na zajęciach lekcyjnych, które są zaliczane do czasu przeznaczonego na obowiązki. W celu porównania uzyskanych wyników z danymi z GUS wzięto pod uwagę dane dotyczące godzin pracy zawodowej oraz długości czasu spędzonego w szkole. Wyliczono, że na zajęcia obowiązkowe Polak przeznacza średnio 6 godzin i 47 minut, co pokazuje, że piłkarki nożne wpisały się w statystyczną liczbę godzin poświęcanych przez Polaków na codzienne obowiązki.

Piłkarki po szkole/pracy udawały się zazwyczaj na trening, który w każdej drużynie trwał średnio ok. półtorej godziny (rys. 6). Różnic doszukano się w liczbie treningów w ciągu tygodnia, ponieważ zespoły grające w wyższych ligach miały więcej jednostek treningowych.

Drużyna UKS SMS Łódź, która znajdowała się w najwyższej lidze rozgrywkowej w Polsce, wymagała solidnego oraz profesjonalnego przy- 
gotowania, stąd też miała najwięcej jednostek treningowych (tj. pięć). Po trzy treningi w tygodniu odbywały się w MUKS Dargfil Tomaszów Mazowiecki oraz UKS Piotrcovia. O ile liczba treningów pierwszoligowego zespołu z Tomaszowa nie wzbudzała zdziwienia, o tyle u dziewcząt z Piotrkowa, które grały w III lidze, wydawała się zbyt duża. Jednakże liczba treningów wynikała z tego, że zawodniczki Piotrcovi uczęszczały do klasy sportowej, gdzie treningi odbywały się w ramach zajęć wychowania fizycznego. Piłkarki z ULKS MOSiR Sieradz i UMKS Zgierz miały najmniej treningów, bo zaledwie po dwa spotkania w tygodniu.

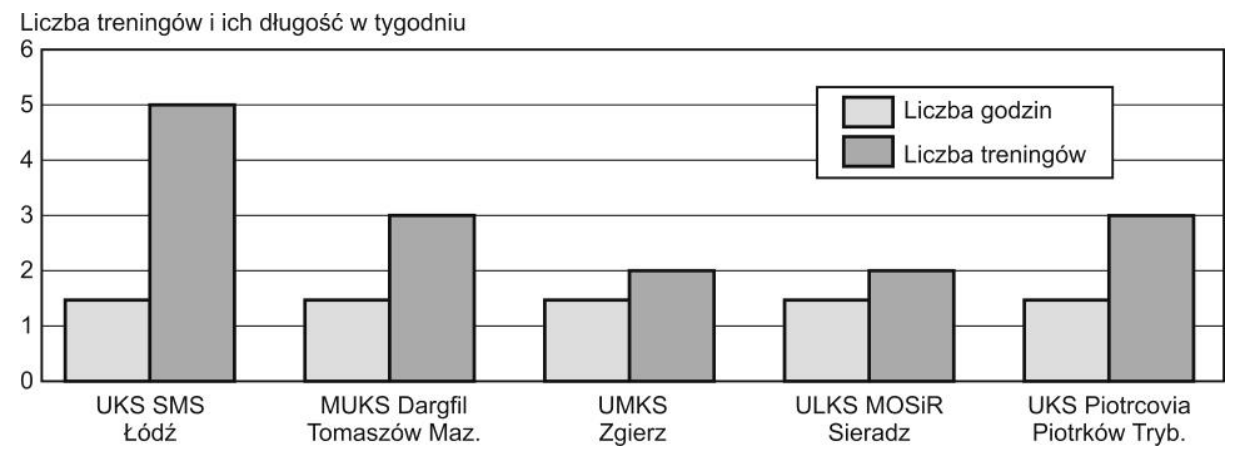

Rys. 6. Liczba treningów w tygodniu oraz czas ich trwania w badanych drużynach kobiecej piłki nożnej w 2016 r.

Dzięki przeprowadzonym badaniom udało się uchwycić różnice co do ilości czasu $\mathrm{w}$ tygodniu poświęcanego przez respondentki z badanych drużyn na aktywność rekreacyjną. W ciągu dnia najwięcej czasu spędzały czynnie piłkarki z UKS SMS Łódź oraz MUKS Dargfil Tomaszów Mazowiecki - średnio 1 godzinę i 20 minut, natomiast dla pozostałych trzech zespołów wskaźnik ten nie przekraczał 1 godziny (rys. 7).

Niewątpliwie mogła mieć na to wpływ liga, do której należała drużyna, gdyż zawodniczki z Łodzi oraz Tomaszowa Mazowieckiego grały w najwyższych ligach rozgrywkowych i efektem tego jest wyższy poziom sportowy. Piłkarki grające na wyższych szczeblach rozgrywek sportowych mają zazwyczaj świadomość korzystnego wpływu podejmowanej przez nie różnej aktywności rekreacyjnej, która w mniejszym lub większym stopniu przekłada się na ich lepszą grę. Wiedzą, że aby stale podnosić poziom swojej sprawności i osiągać coraz lepsze wyniki oraz utrzymać dobrą kondycję fizyczną, muszą podejmować dodatkową aktywność fizyczną, ponieważ sam trening nie wystarczy. Okazuje się, że istotne znacznie ma także poziom 
wykształcenia zawodniczek, ponieważ właśnie w drużynach z Łodzi i Tomaszowa występował najwyższy odsetek respondentek, które ukończyły studia (por. rys. 4).

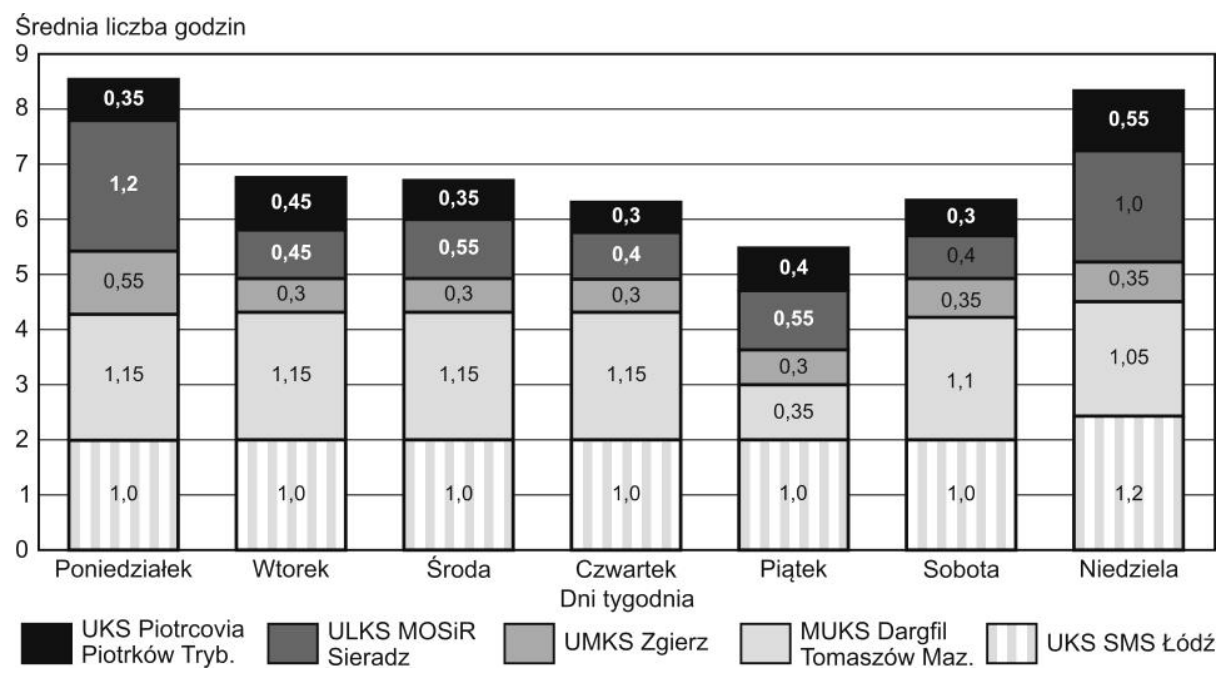

Rys. 7. Liczba godzin poświęcanych w tygodniu na aktywność rekreacyjną czynną przez respondentki w 2016 r.

Opierając się na przedstawionych wyżej wnioskach, można stwierdzić, że postawiona przed badaniami hipoteza, zakładająca, że $w$ im wyższej lidze rozgrywkowej znajduje się drużyna zawodniczki, tym aktywniej spędza ona czas wolny, została potwierdzona.

\section{Aktywność rekreacyjna piłkarek nożnych z województwa łódzkiego}

Zawodniczki z łódzkich drużyn piłki nożnej swoją aktywność z boiska przenosiły na czas wolny. Zaobserwowano wpływ uprawiania sportu, który jest ważnym elementem w życiu zawodniczek, na sposób spędzania ich czasu wolnego. Ponad 30\% piłkarek w otwartym pytaniu o zainteresowania wpisało sport grupowy (rys. 8). Co ciekawe, co czwarta osoba jako dominującą dyscyplinę uprawianą $\mathrm{w}$ czasie wolnym wymieniała piłkę nożną. Sumując obie odpowiedzi, stwierdzono, że na ogół sportem interesuje się prawie $60 \%$ respondentek. Takie odpowiedzi mogą nieznacznie 
sugerować, iż piłkarki, uznając sport za swoje główne zainteresowanie, spędzają aktywnie czas wolny. Pojawiły się także zajęcia niezwiązane ze sportem, takie jak: słuchanie muzyki (14\%), oglądanie filmu (9,5\%) czy czytanie książki (4\%), a dwie respondentki jako swoje hobby wymieniły motoryzację, choć na ogół jest ona uważana za pasję mężczyzn.

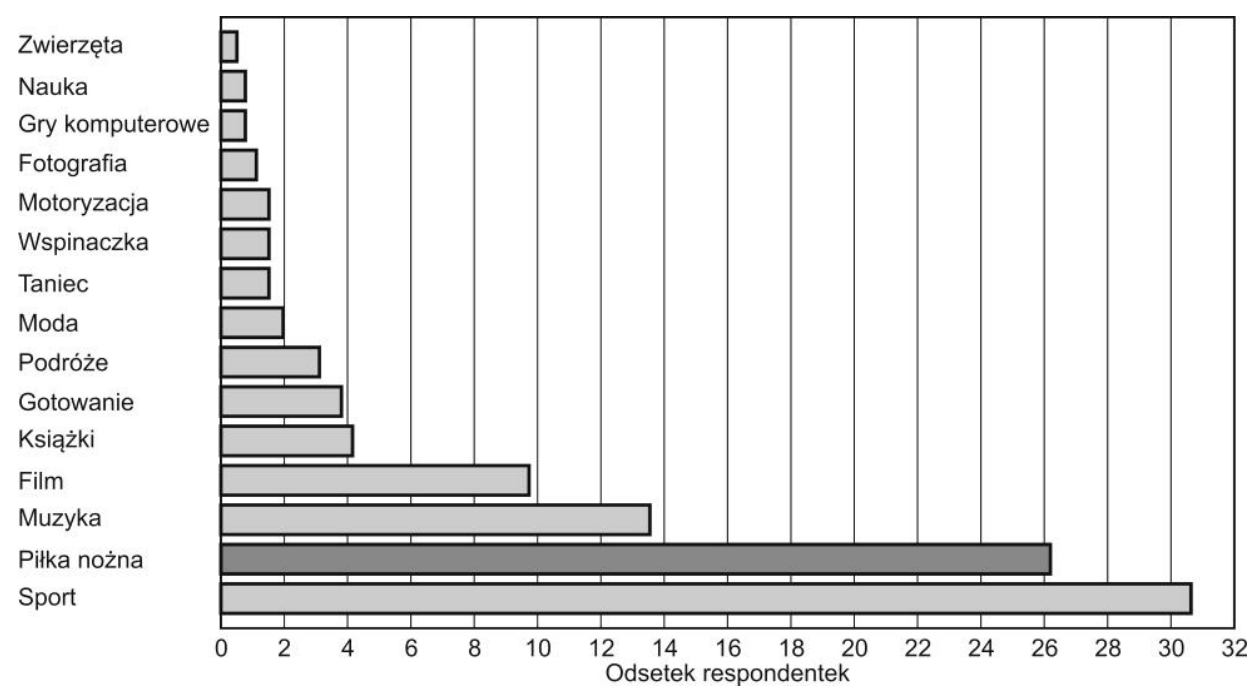

Rys. 8. Zainteresowania respondentek $\mathrm{z}$ badanych drużyn w 2016 r. $(n=268)$

Choć piłkarki podejmowały wszelkie rodzaje aktywności w czasie wolnym z różnych przyczyn, powodem najczęściej wskazywanym (przez ponad $20 \%$ zawodniczek) była chęć rozrywki i zabawy. Kolejnymi ważnymi motywami okazały się: dbanie o własne zdrowie oraz spotkania ze znajomymi, a dla 15\% respondentek sport był formą rozładowania stresu (rys. 9).

Piłkarki nożne zostały poproszone o wymienienie rodzajów własnej aktywności rekreacyjnej, której oddają się w dwóch okresach roku - jesienią oraz w wakacje. Analizując dane, zaobserwowano, że respondentki były bardziej aktywne w czasie chłodniejszej pory roku, co zobrazowano na rys. 10. Swój czas poświęcały przede wszystkim na gry zespołowe (130 deklaracji), a 115 zawodniczek wskazało pływanie (basen) jako najchętniej uprawianą formę aktywności. Równie dużym zainteresowaniem cieszyły się w okresie jesiennym: jazda na rowerze, jogging, spacery oraz zajęcia na siłowni. W grupie innych form aktywności kilka piłkarek zamieściło jazdę konną. 


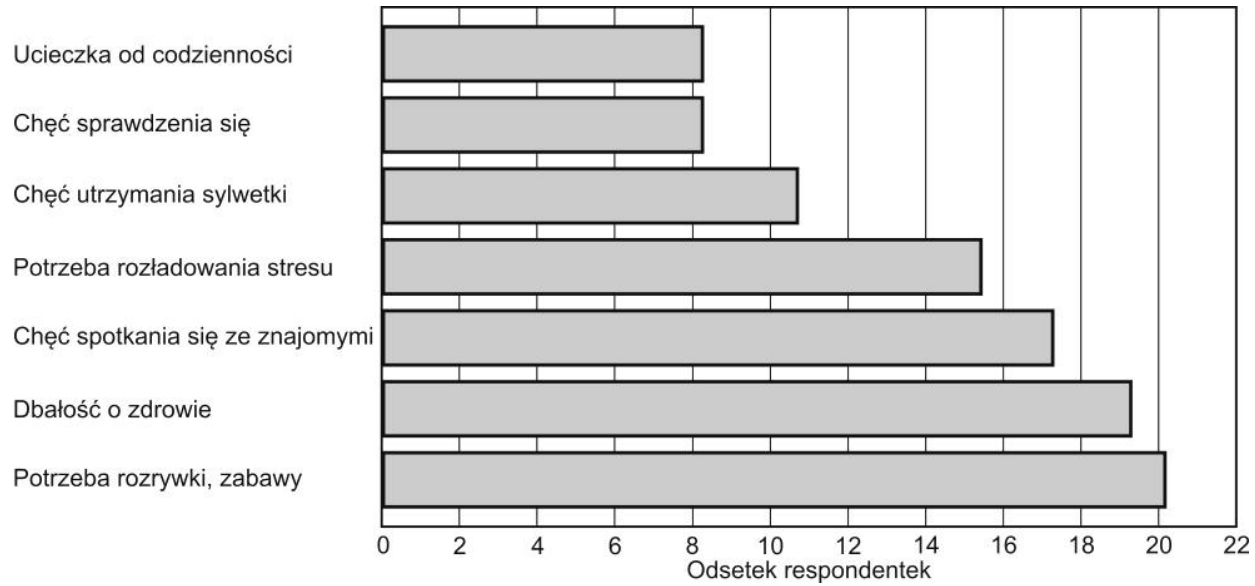

Rys. 9. Powody podejmowania aktywności rekreacyjnej w czasie wolnym przez respondentki w 2016 r. $(n=362)$

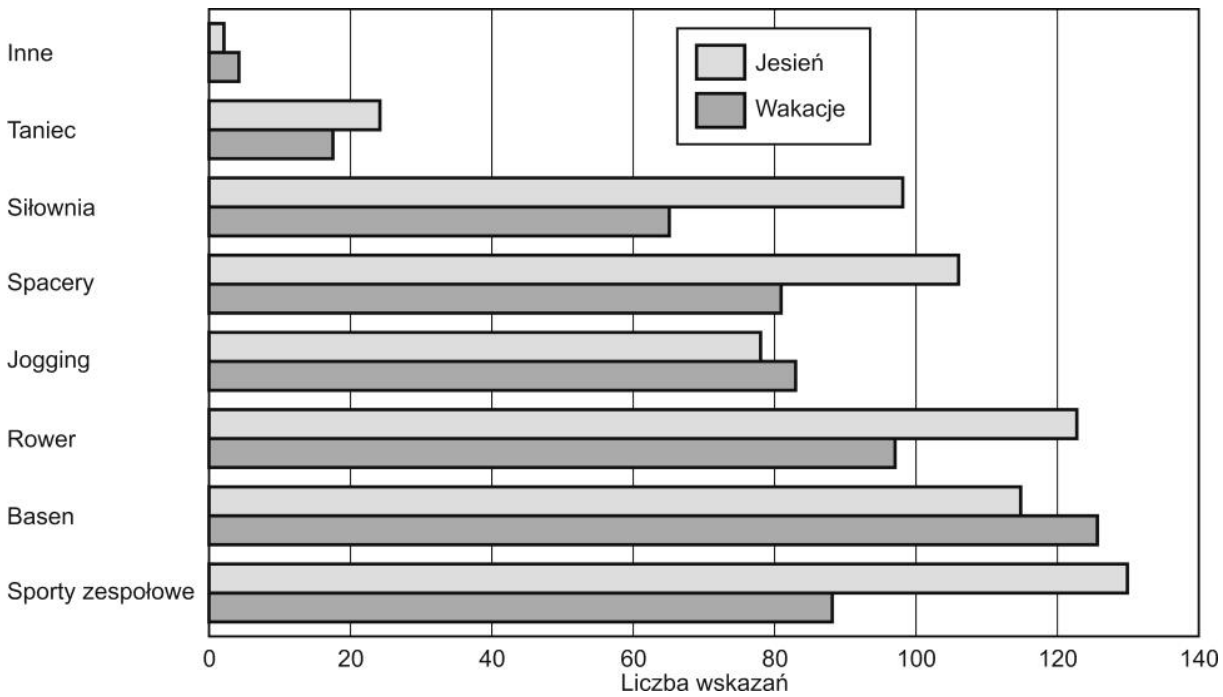

Rys. 10. Najczęściej wybierane sposoby aktywnego spędzania czasu wolnego jesienią $(n=590)$ oraz $w$ wakacje $(n=647)$ przez respondentki $w 2016 r$.

W okresie wakacyjnym zawodniczki także podejmowały wzmożoną aktywność rekreacyjną, lecz nieco mniejszą niż na jesieni. Największą zmianę liczby rodzajów aktywności czynnej można zaobserwować w sportach 
zespołowych, odnotowano ich bowiem o 42 wskazania mniej niż jesienią. Niewielki wzrost liczby wskazań nastąpił w odniesieniu do joggingu. Natomiast uczęszczanie na basen wzrosło ze 115 do 126 deklaracji, choć na zwiększenie tej aktywności latem wpłynęły zapewne wysokie temperatury tej pory roku.

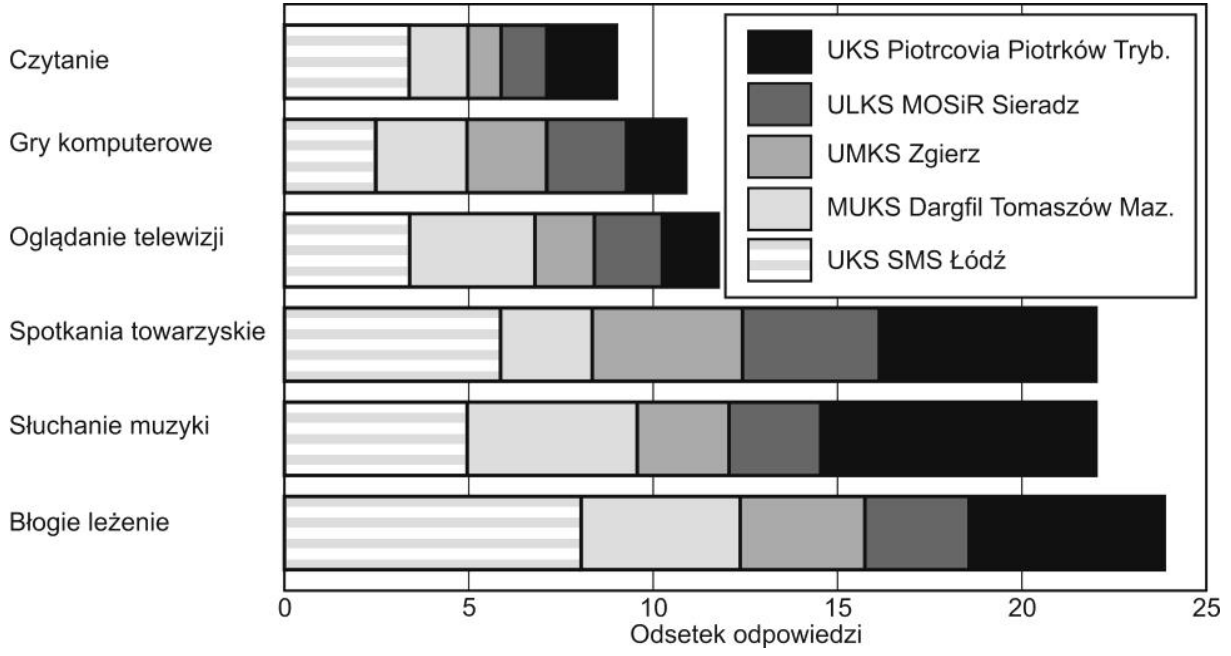

Rys. 11. Rodzaje aktywności biernej jako formy spędzania czasu wolnego przez respondentki w 2016 r. $(n=323)$

Kolejnym aspektem badań prowadzonych wśród piłkarek nożnych z woj. łódzkiego był bierny sposób spędzania czasu wolnego, co zobrazowano na rys. 11 . W przypadku tego pytania respondentki miały możliwość wielokrotnego wyboru odpowiedzi i z uzyskanych danych wynika, że najczęściej wybieraną formą rekreacji biernej było błogie leżenie. Najwięcej takich odpowiedzi ( $7 \%$ z $24 \%$ uzyskanych) udzieliły zawodniczki UKS SMS Łódź, czyli ekstraligowa drużyna z pięcioma treningami w tygodniu, której reprezentantki ceniły sobie taki czas przeznaczony na regenerację sił fizycznych. Z tym samym odsetkiem odpowiedzi (po 22\%) odnotowano słuchanie muzyki (tę czynność najwięcej razy wymieniły zawodniczki UKS Piotrcovia) oraz uczestnictwo w spotkaniach towarzyskich (w których najczęściej brały udział zawodniczki z Łodzi). Najrzadziej w ramach biernego sposobu spędzania czasu wolnego piłkarki sięgały po książki $(8,5 \%)$. 


\section{Podróże i aktywność turystyczna piłkarek nożnych w 2016 roku}

Badania autorki obejmowały również aktywność turystyczną respondentek. Do wyjazdów turystycznych piłkarek nożnych zostały zaliczone obozy sportowe, ponieważ na obozach w czasie wolnym od treningów zawodniczki uczestniczą $\mathrm{w}$ różnych formach rekreacji, a także korzystają $\mathrm{z}$ oferty turystycznej miasta, w którym trenują. W 2016 r. na 132 ankietowane zawodniczki aż 107 udało się poza miejsce swojego zamieszkania w celach turystycznych. Najwięcej podróży turystycznych odbyły przedstawicielki drużyny UKS SMS Łódź (27 osób), a dokładną liczbę wyjeżdżających zawodniczek zobrazowano w tab. 2.

Tab. 2. Badane piłkarki nożne z woj. łódzkiego, które w 2016 r.

podjęły podróże turystyczne

\begin{tabular}{|l|c|c|c|}
\hline \multirow{2}{*}{\multicolumn{1}{|c|}{ Drużyna }} & \multirow{2}{*}{$\begin{array}{l}\text { Ogółem } \\
\text { piłkarki }\end{array}$} & \multicolumn{2}{c|}{ Podróżujące piłkarki } \\
\cline { 3 - 4 } & 35 & 27 & 77,1 \\
\hline UKS SMS Łódź & 26 & 24 & 92,3 \\
\hline MUKS Dargfil Tomaszów Mazowiecki & 20 & 14 & 70,0 \\
\hline UMKS Zgierz & 21 & 18 & 85,7 \\
\hline ULKS MOSiR Sieradz & 30 & 24 & 80,0 \\
\hline UKS Piotrcovia Piotrków Trybunalski & 132 & 107 & 81,1 \\
\hline Ogółem & & &
\end{tabular}

Źródło: opracowanie własne na podstawie wyników badań ankietowych w 2017 r.

Celem 131 ze 177 wszystkich podróży były miejsca w granicach Polski, z czego wynika, że zawodniczki preferowały wycieczki krajowe, które stanowiły $74 \%$ całości wyjazdów turystycznych. Mapa krajowych wyjazdów turystycznych piłkarek nożnych z województwa łódzkiego (rys. 12) pokazuje, że respondentki wybierały zdecydowanie północną oraz południową część Polski. Częściej kierowały się na północ kraju, dokąd podróżowały przede wszystkim w lipcu oraz sierpniu. Wyjazdy te miały zazwyczaj charakter wypoczynkowy. Na północy Polski zawodniczki odwiedziły 15 miast, w tym Władysławowo, które było najczęściej wymienianą miejscowością (przez 25 piłkarek). Duży wpływ na taki kierunek podróży mogły mieć wskazania zawodniczek z Tomaszowa Mazowieckiego, ponieważ piłkarki z tamtego klubu w 2016 r. miały zorganizowany we Władysławowie obóz sportowy. Podobnie sytuacja przedstawiała się w miastach Pokrzyw- 
na (powiat nyski, 7 wyjazdów), gdzie piłkarki z Piotrkowa Trybunalskiego odbywały obóz przygotowawczy, oraz Ruda (powiat sieradzki, 15 wyjazdów), dokąd wyjechały na taki obóz zawodniczki z Sieradza. W centralnej części kraju wyjazdy trwały ok. trzech dni i miały charakter odwiedzin $\mathrm{u}$ rodziny lub znajomych. Respondentki odbyły 46 podróży turystycznych na tereny wysokogórskie oraz górskie, przy czym największa koncentracja wyjazdów miała miejsce w rejon Karpat, choć w przeprowadzonych ankietach na mapie wyjazdów turystycznych zawodniczek dwukrotnie pojawiły się Sudety.

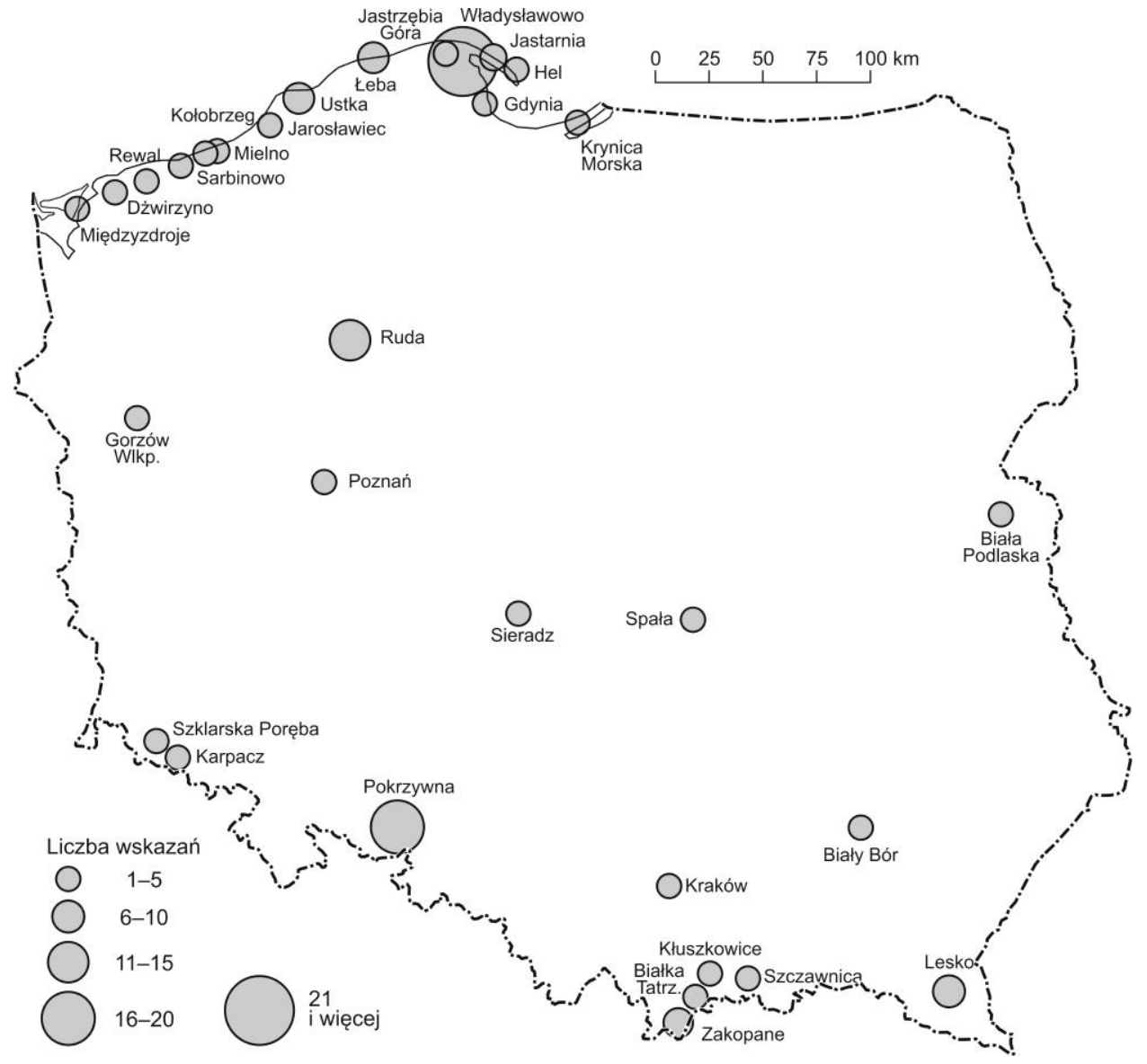

Rys. 12. Turystyczne wyjazdy krajowe ankietowanych piłkarek nożnych z woj. łódzkiego w 2016 r. $(n=131)$ 
Piłkarki w 2016 r. odbyły również 46 zagranicznych wyjazdów turystycznych, których zasięg zawęził się do krajów europejskich (rys. 13). Tego typu podróże charakteryzowały się zwiększoną liczbą dni pobytu, gdyż podróż trwała średnio 11 dni. Najliczniej (11 wskazań) zawodniczki odwiedzały Grecję, choć wskazywanym równie często krajem była Chorwacja (10 odpowiedzi) oraz Hiszpania (8). Odnotowano po jednym wyjeździe do Albanii, Gruzji, Ukrainy, Niemiec i Portugalii.

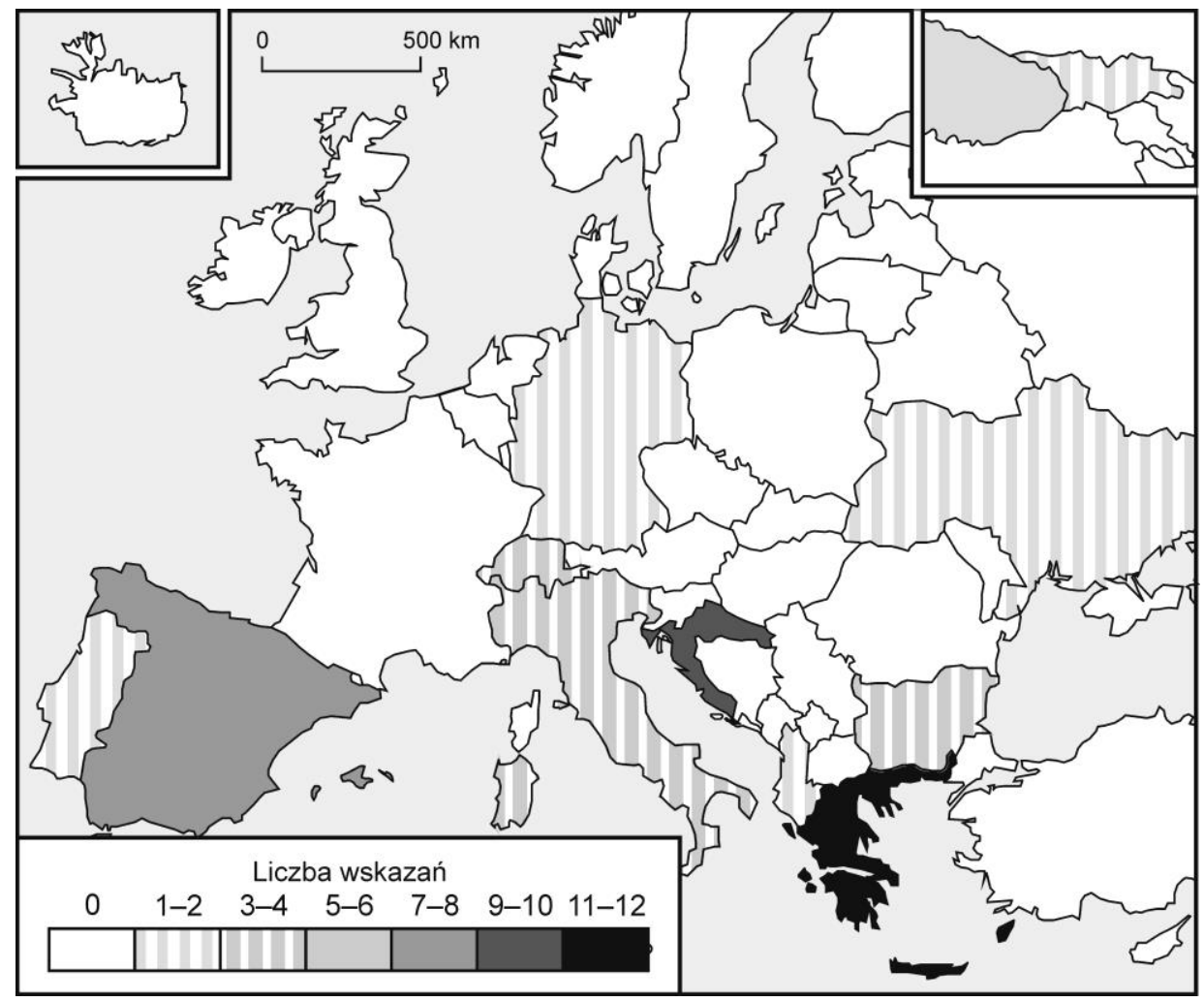

Rys. 13. Turystyczne wyjazdy zagraniczne piłkarek nożnych z woj. łódzkiego w 2016 r. ( $\mathrm{n}=46)$

Największe natężenie podróży turystycznych nastąpiło w lipcu (40 wyjazdów) oraz sierpniu (48 wyjazdów), pozostałe miesiące natomiast raczej odznaczały się pojedynczymi wyjazdami, oprócz czerwca (6 wyjazdów) i września (3 wyjazdy). W kwietniu i w maju piłkarki nie odbyły żadnej podróży turystycznej, co mogło być spowodowane tym, że czas ten obfituje w ważne dla uczniów egzaminy gimnazjalne oraz maturalne. Ponadto 
na przełomie tych miesięcy trwa piłkarska runda wiosenna, która jest istotniejsza od rundy jesiennej, gdyż wiosna kończy cały sezon sportowy i są wtedy wyłaniane drużyny piłki nożnej, które zdobędą mistrzostwo $\mathrm{w}$ danej lidze, a także tzw. spadkowicze. $\mathrm{Z}$ tego powodu zawodniczki znacznie bardziej mobilizują się na wiosnę oraz skupiają na dobrym przygotowaniu i grze, odkładając na dalszy plan podróże turystyczne.

Jeśli chodzi o długość trwania wyjazdu turystycznego (krajowego oraz zagranicznego), to piłkarki przeznaczały na to przeciętnie niecałe sześć dni (dokładnie 5,5 dnia), a najdłuższe podróże, odnotowane w sierpniu, trwały nieco ponad osiem dni (rys. 14). Pozostałe wyjazdy mieściły się w przedziale od sześciu do ośmiu dni, z wyjątkiem marca, kiedy podróż turystyczna trwała średnio pięć dni, oraz listopada - trzy dni. Z badań CBOS (2017) wynika, że statystyczny Polak w 2016 r. na wyjazdy turystyczne poświęcał średnio siedem dni. Po zestawieniu ze sobą tych danych widać, że piłkarki nożne charakteryzuje nieco niższa średnia długość trwania podróży turystycznych.

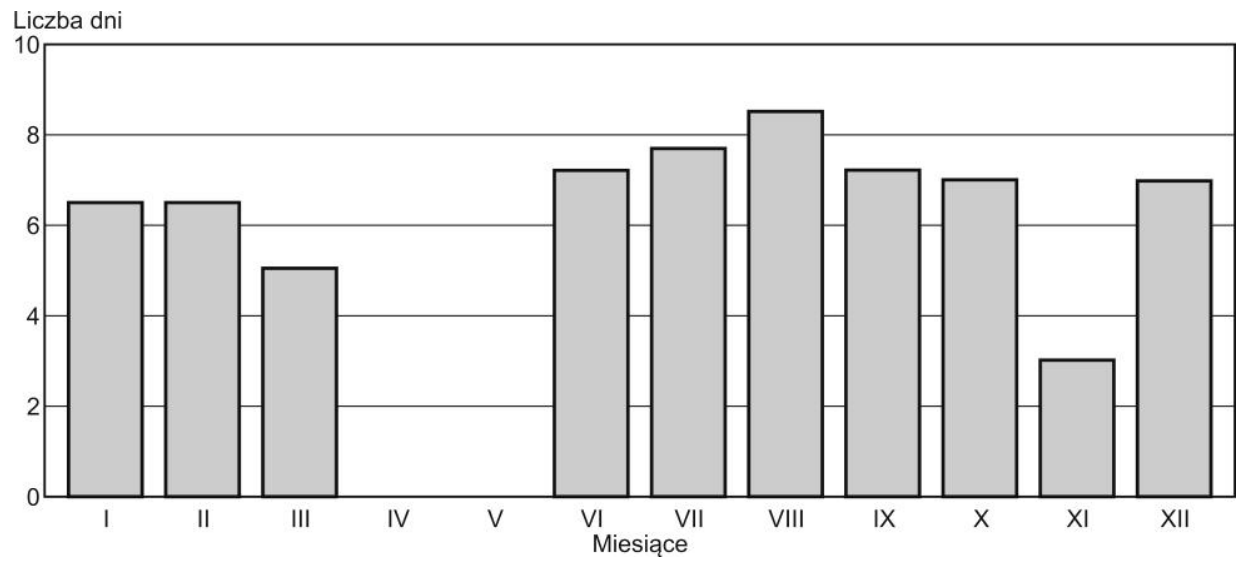

Rys. 14. Średnia liczba dni przeznaczonych w 2016 r. na wyjazd turystyczny przez badane piłkarki nożne $(\mathrm{n}=177)$

Badania autorki pokazały, że powody wyjazdów turystycznych w każdej drużynie są różne, co zobrazowano na rys. 15. Jako główny motyw wyjazdów wskazywano spokojny wypoczynek, co może dowodzić, że okres letni był dla piłkarek czasem, kiedy mogły odpocząć i zregenerować siły.

Analizie poddano także sposoby spędzania czasu wolnego przez piłkarki nożne podczas podróży turystycznych. Badania wykazały, że 
niecałe $20 \%$ respondentek przeznaczyło czas wolny na życie towarzyskie oraz chodzenie do restauracji (rys. 16). Wśród innych rodzajów aktywności biernej pojawiło się także oglądanie telewizji. W kilku przypadkach $\mathrm{w}$ ramach innych sposobów spędzania czasu wolnego zawodniczki wymieniły dodatkowo: trening mentalny, naukę języka obcego oraz wędrowanie po górach.

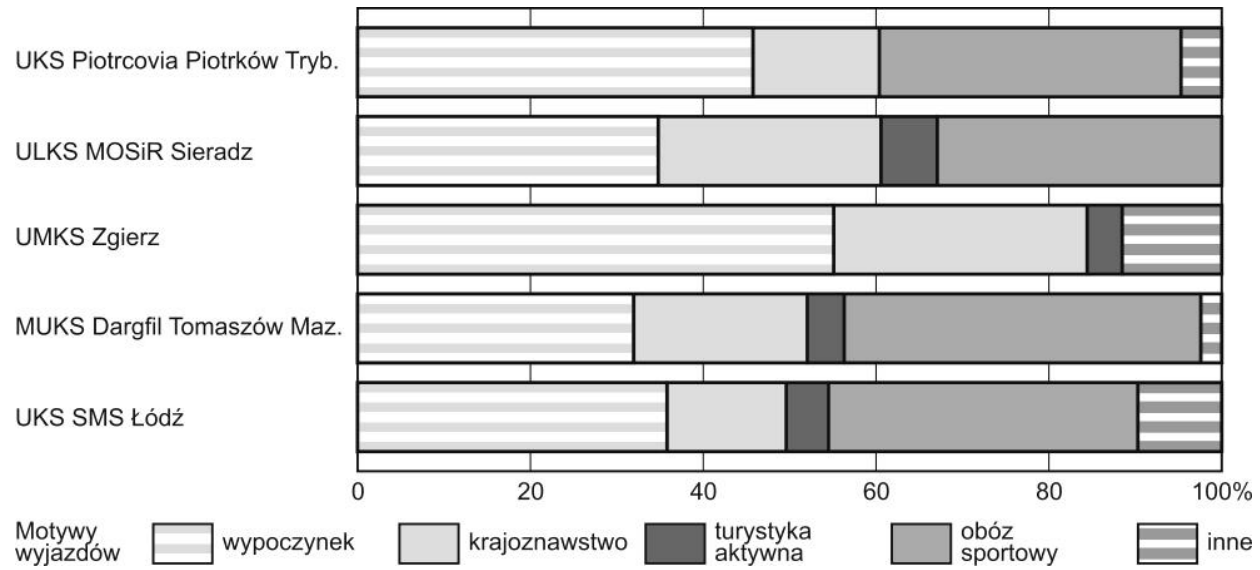

Rys. 15. Motywy wyjazdów turystycznych badanych piłkarek nożnych (n = 216)

Inne

Kult religijny

Rehabilitacja

Wydarzenia kulturalne

Oglądanie telewizji

Chodzenie do restauracji

Życie towarzyskie

Spokojny wypoczynek

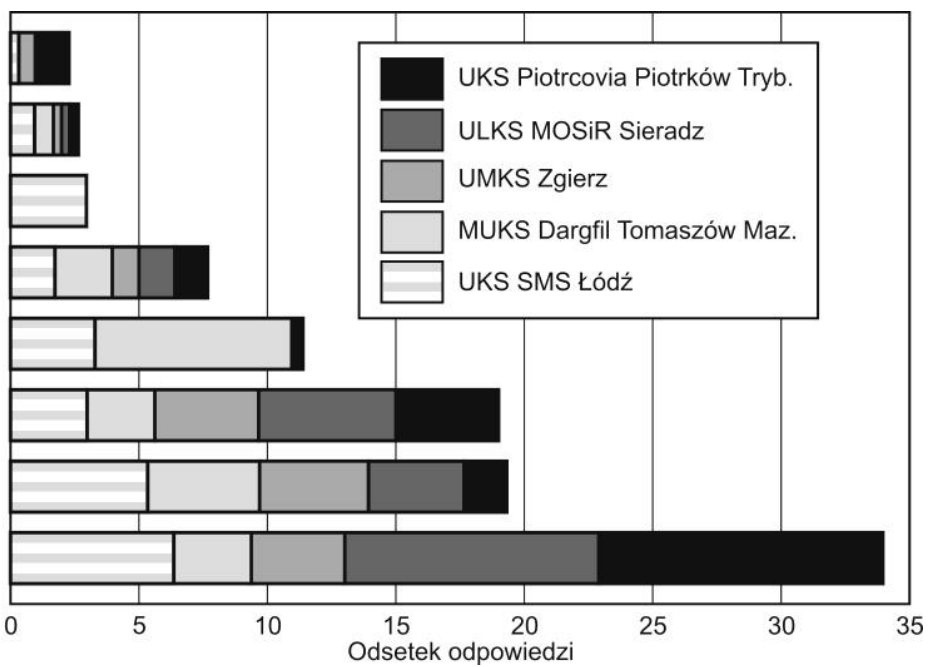

Rys. 16. Sposoby spędzania czasu wolnego przez ankietowane piłkarki nożne podczas wyjazdów turystycznych $(\mathrm{n}=300)$ 


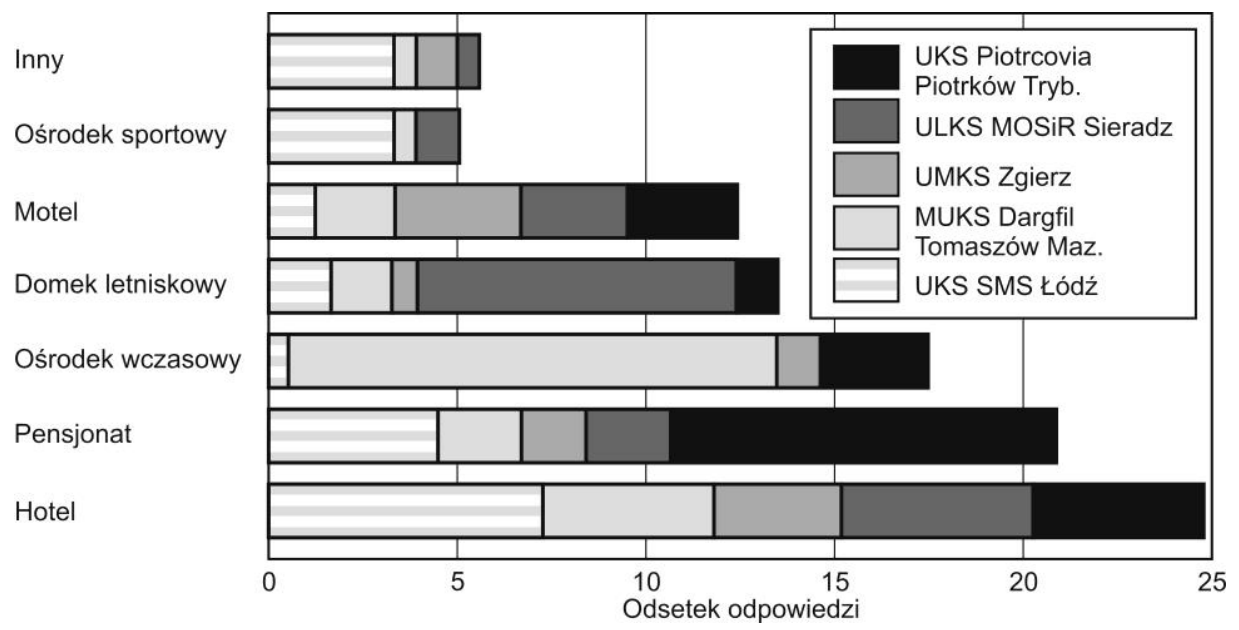

Rys. 17. Rodzaje obiektów noclegowych wykorzystywanych podczas wyjazdów turystycznych przez respondentki w 2016 r. (n = 177)

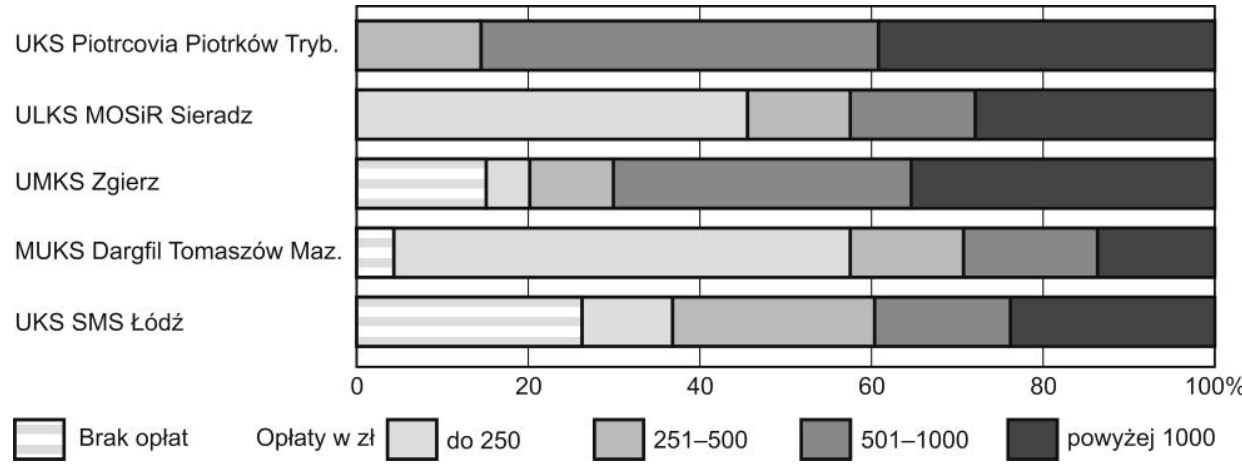

Rys. 18. Kwoty przeznaczane przez respondentki na wyjazdy turystyczne w 2016 r. $(n=177)$

Badano również, jakie preferencje dotyczące obiektów noclegowych mają piłkarki nożne podczas odbywania podróży turystycznych. Najczęściej wskazywaną przez zawodniczki bazą noclegową były hotele, zaraz za nimi znalazły się pensjonaty (21 zawodniczek), wybierane przede wszystkim przez respondentki z Tomaszowa Mazowieckiego (13\%). Piłkarki podczas wyjazdów turystycznych rzadziej korzystały z domków letniskowych i moteli. Co ciekawe, tylko 15\% ankietowanych wybierało zakwaterowanie w ośrodkach sportowych, które wydawać by się mogło, będą głównie wykorzystywane ze względu na dobre zaplecze treningowe i dogodne warunki 
do zorganizowania obozu sportowego. Zawodniczki w dodatkowych odpowiedziach jako chętnie wybieraną bazę noclegową wskazywały też nocleg $\mathrm{u}$ znajomych lub rodziny, w akademiku oraz wynajętym pokoju (rys. 17).

Piłkarki z województwa łódzkiego przeznaczały różne kwoty na swoje wyjazdy turystyczne, ale niektóre podróże były dla nich bezpłatne (obóz sportowy). W pierwszoligowym i drugoligowym zespole przeznaczane na wyjazdy sumy oscylowały wokół 250-500 zł (rys. 18). Najwięcej pieniędzy na wyjazdy turystyczne wydawały natomiast zawodniczki z zespołu UKS Piotrcovia, wskazując najczęściej przedział od 501 do 1000 zł.

\section{Profil piłkarki nożnej z województwa łódzkiego uwzględniający zachowania rekreacyjno-turystyczne}

Po przeanalizowaniu zebranego materiału badawczego stwierdzono, że łódzkie piłkarki nożne odznaczają się stosunkowo dużą aktywnością zarówno rekreacyjną, jak i turystyczną. Dzięki uzyskanym wynikom badań udało się opracować profil piłkarki nożnej z województwa łódzkiego pod względem zachowań rekreacyjno-turystycznych.

Według autorki piłkarka nożna to kobieta w wieku około 19 lat z podstawowym wykształceniem, ale uczęszczająca do szkoły średniej. Pochodzi z województwa łódzkiego, gdzie mieści się także jej klub sportowy.

Zawodniczka spędza dziennie średnio 7 godzin w szkole/pracy, po czym udaje się na trening. W ciągu tygodnia odbywa trzy jednostki treningowe, z czego każda trwa jednorazowo 1,5 godziny, natomiast w weekend piłkarka rozgrywa mecze ligowe. Na rekreację bierną dziennie przeznacza średnio ok. 1 godziny i 20 minut, oddając się podczas tego wypoczynku najczęściej błogiemu leżeniu, słuchaniu muzyki bądź spotkaniom towarzyskim ze znajomymi. Mniej czasu znajduje na rekreację czynną, gdyż w ciągu dnia ma na to 40 minut.

W życiu zawodniczki sport ma ogromne znaczenie. Piłkarka nożna swój czas wolny spędza aktywnie (zazwyczaj uprawiając sport), gdyż jest to dla niej forma zabawy i rozrywki. Nie zapomina jednak, że ruch jest zbawienny dla jej zdrowia i lepszego samopoczucia. Bardziej aktywna jest $\mathrm{w}$ okresie jesiennym niż wakacyjnym, mimo że jest to pora nakładania się na siebie różnych obowiązków. W związku z tym zawodniczka podejmuje czynności rekreacyjne zazwyczaj trzy razy w ciągu tygodnia. W czasie 
wolnym bardzo chętnie uczestniczy w grach zespołowych, takich jak: piłka nożna, piłka siatkowa czy koszykówka, a także z ochotą pływa (na basenie), jeździ na rowerze, uprawia jogging oraz chodzi na spacery i na siłownię.

W okresie letnim wyjeżdża turystycznie jeden bądź dwa razy na przełomie lipca oraz sierpnia i przeznacza na podróż średnio ponad $500 \mathrm{zł}$. Jedna podróż odbywa z zamiarem wypoczynku i regeneracji sił, a celem drugiej jest obóz sportowy. Wyjazdy trwają ok. sześciu dni, a miejscem docelowym są polskie góry bądź morze. Na wyjeździe turystycznym piłkarka zazwyczaj odpoczywa, ale także podejmuje różne rodzaje aktywności biernej, biorąc udział w spotkaniach towarzyskich czy oglądając telewizję.

\section{Wnioski}

Na podstawie przeprowadzonych badań ankietowych na temat spędzania czasu wolnego przez zawodniczki pięciu klubów piłki nożnej z województwa łódzkiego sformułowano kilka wniosków. Przede wszystkim stwierdzono, że piłkarki nożne z województwa łódzkiego mają mało czasu wolnego w porównaniu z osobami nieuprawiającymi wyczynowo sportu. Do swoich zajęć obowiązkowych muszą włączyć także treningi oraz mecze, przez co znacznie skraca się ich czas wolny zarówno w ciągu dnia, jak i w ciągu tygodnia.

Aktywność rekreacyjno-turystyczna zawodniczek z poszczególnych klubów nie ma cech szczególnie je wyróżniających. Mimo różnic występujących w każdej drużynie badane piłkarki czas wolny spędzają w głównej mierze aktywnie. Poświęcają go na różne formy aktywności ruchowej, skupiając się na innych dyscyplinach sportowych, natomiast spośród form rekreacji biernej szczególnie preferują spokojny wypoczynek - błogie leżenie, co pozwala im wyciszyć się oraz odpocząć po wysiłku i nabrać sił do odbycia kolejnych treningów i meczy.

Podróże turystyczne ankietowanych zawodniczek wpisują się w główne kierunki wyjazdów Polaków. Piłkarki decydują się raczej na podróże krajowe, wybierając rejony nadmorskie oraz górskie. Destynacjami zagranicznymi były z kolei państwa o popularnych walorach turystycznych, takie jak: Grecja, Hiszpania czy Chorwacja. 


\title{
Bibliografia
}

Budżet czasu ludności 2013 (2015). Warszawa: Zakład Wydawnictw Statystycznych, GUS.

Daleszczyk, G. (2018). Aktywność rekreacyjno-turystyczna w czasie wolnym piłkarek nożnych z województwa łódzkiego. Mps pracy magisterskiej. Łódź: Uniwersytet Łódzki.

Miejski Ośrodek Sportu i Rekreacji w Sieradzu. Pobrane z: http://www.mosirsieradz.pl (01.06.2018).

Pol, M. (2016). Encyklopedia piłki nożnej. Poznań: Wydawnictwo Publicat.

Viard, J. (2002). Le sacre du temps libre, la société des 35 heures. Paris: Wydawca Éditions de l'Aube. WP. Kobieta. Pobrane z: https://kobieta.wp.pl/ (27.03.2018).

\section{AKTYWNOŚĆ REKREACYJNO-TURYSTYCZNA W CZASIE WOLNYM PIŁKAREK NOŻNYCH Z WOJEWÓDZTWA ŁÓDZKIEGO}

\begin{abstract}
Abstrakt: Celem autorki pracy jest analiza czasu wolnego piłkarek nożnych z klubów sportowych w województwie łódzkim. W kręgu zainteresowań badawczych znalazły się takie zagadnienia, jak: czas wolny piłkarek, sposób jego wykorzystania, wielkość i struktura wyjazdów turystycznych w 2016 r. Próbowano ustalić, czym wyróżnia się aktywność rekreacyjno-turystyczna zawodniczek. Stwierdzono, że wykazują one dużą aktywność w czasie wolnym. Na intensywność i czas jej trwania wpływa wiele czynników. Główną metodą badawczą był wywiad kwestionariuszowy, który został skierowany do zawodniczek z pięciu łódzkich klubów piłkarskich. Dodatkowo wykonano inwentaryzację bezpośrednią sportowych obiektów badanych klubów.
\end{abstract}

Słowa kluczowe: czas wolny, aktywność rekreacyjna, aktywność turystyczna, piłkarki nożne, województwo łódzkie.

\section{LEISURE TIME TOURIST-RECREATION ACTIVITY OF FEMALE FOOTBALL PLAYERS FROM LODZ REGION}

\begin{abstract}
The aim of the work is to analyze the free time of footballers belonging to sports clubs in the Lodz region. In the area of interest, there were such issues as: free time of footballers, the way of using them, size and structure of tourist trips in 2016. An attempt to determine what distinguishes the recreational and recreational activity of female players. It was found that they exhibit high activity in their free time. Many factors affect the intensity and duration of activity. The main research method was a questionnaire interview, which was directed to players from five Lodz football clubs. In addition, a direct inventory of sports facilities of the examined clubs was carried out.
\end{abstract}

Keywords: free time, recreational activity, tourist activity, female football, Łódź Province. 